\title{
Fluxgate gradiometry survey at North Leigh Roman Villa, Oxfordshire
}

Article

Accepted Version

Creighton, J. and Allen, M. (2017) Fluxgate gradiometry survey at North Leigh Roman Villa, Oxfordshire. Britannia, 48. pp. 279-287. ISSN 0068-113X doi:

https://doi.org/10.1017/S0068113X17000022 Available at https://centaur.reading.ac.uk/68905/

It is advisable to refer to the publisher's version if you intend to cite from the work. See Guidance on citing.

To link to this article DOI: http://dx.doi.org/10.1017/S0068113X17000022

Publisher: Cambridge University Press

All outputs in CentAUR are protected by Intellectual Property Rights law, including copyright law. Copyright and IPR is retained by the creators or other copyright holders. Terms and conditions for use of this material are defined in the End User Agreement.

\section{www.reading.ac.uk/centaur}

\section{CentAUR}

Central Archive at the University of Reading

Reading's research outputs online 


\section{Author's Original Manuscript - Postprint}

This is an Author's Accepted Manuscript of an article to be published as Creighton, J. and Allen, M. (2017) Fluxgate Gradiometry Survey at North Leigh Roman Villa, Oxfordshire. In Britannia, Volume 48. Accepted December 2016

Cambridge University Press, available online at: https://www.cambridge.org/core/journals/britannia

\section{Fluxgate Gradiometry Survey at North Leigh Roman Villa, Oxfordshire}

John Creighton and Martyn Allen, University of Reading, write: North Leigh Roman villa ranks as one of the largest known courtyard villas of Roman Britain. ${ }^{1}$ Situated just above the floodplain of the River Evenlode, which loops around the site, the villa lies approximately 2 miles north of North Leigh village and 10 miles west of Oxford (SP 397154). The building developed within the Late Iron Age earthwork complex of the North Oxfordshire Grim's Ditch, a discontinuous bank and ditch which partly encloses a 22-square mile area of this landscape. ${ }^{2}$ The villa is under English Heritage guardianship (scheduled ancient monument no. 334573) and a programme of geophysical survey was conducted at their request to assist in management of the site. ${ }^{3}$

\section{HISTORY OF INTERVENTIONS}

The site was first discovered in $1783,{ }^{4}$ and subsequent work there has been summarised well by David Wilson in his guides and publications of the site. ${ }^{5}$ The first major investigations were in 1813-17 when the villa was excavated by the Rector at nearby Hanborough, Walter Brown, and the architect Henry Hakewill. ${ }^{6}$ At least five third-century mosaics were revealed, though after two had been destroyed by souvenir hunters, the landowner, the Duke of Marlborough, commissioned a shed to protect the remaining ones; complemented later with a custodian's cottage to secure the site. $^{7}$

Twentieth-century investigations began in 1910-11 with excavations by Donald Atkinson and Evelyn White, partly observed by Francis Haverfield. ${ }^{8}$ The overall plan of the site was extended with the addition of new buildings from aerial photographs observed by Flight Lieutenant D.N. Riley in $1943 .{ }^{9}$ The chronology was refined during work by Helen O'Neil for the Ministry of Works in 1956-9 which revealed postholes under the northern range of the villa associated with 'Belgic ware'. ${ }^{10}$ The site was partly resurveyed in 1973; ${ }^{11}$ and in 1975-7 small scale excavations took place prior to consolidating some of the remains by Jeffrey West, Jerome Bertram and Angela Lister. ${ }^{12}$ The results were incorporated into the official Department of the Environment 1980 handbook by Wilson ${ }^{13}$. Since then there has been relatively little work, except for a watching brief in 1979 in the field between the Roman Villa and the River Evenlode by Oxford Archaeology Unit. ${ }^{14} \mathrm{~A}$ large drainage ditch, cut from the railway bridge corner up to the field boundary and back to the river again, revealed six large masonry walls, which were suggested by David Miles to have potentially been part of three buildings.

\section{THE DEVELOPMENT OF THE VILLA}

Wilson's work established our current understanding of the overall chronology of the site: 
Period 0: Pre-Roman Iron Age pottery and associated features were found by O'Neil under the former south-west range of the villa, as well as Rooms $4 \& 6$ of the north-west range. 'The pottery was described as Belgic (especially in Rooms 53, 54, and 67), Rhenish (Room 54)'. Residual material in significant quantity was also found under the Period 1 north bath-house. ${ }^{15}$ Collectively this suggests there was fairly extensive pre-villa occupation.

Period 1: The villa itself began in the 1st or 2nd century AD as a series of three buildings comprising the north bath-house with two further buildings to the south-west. Over time these were linked together to form one long structure with a linking corridor, which became the northwest range. Wilson identified 5 sub-phases A-E within this in his interpretation of this development. ${ }^{16}$

Period 2: Later, the north-west range was totally rebuilt, with the Period 1 remains demolished and used only as foundations. Early in the third century (our chronology is imprecise) the south-west and north-east wings were added, partially enclosing the courtyard. Wilson observed that the north-east range was 'constructed over made ground (apparently a filled-in gravel pit), which led to subsidence of walls and floors at the south-west end of Rooms 29 and 30,17. This north-east range included a second bath-house (the 'East Baths'). The south-west range was interpreted as being given over to 'workshops and outbuildings'. The range is interpreted as containing a stable (underlying rooms 53-55), and at the far end a barn (room 63) in to which a bath suite was later added. Separating them was another gravel pit, $3.7 \times 15 \mathrm{~m}$ as much as $2.8 \mathrm{~m}$ deep. Eventually when a linking corridor erecting a unified façade onto all of these building was added, special measures were taken to support the walls over this. To the south-east a new imposing entrance was constructed. By the end of Period 2 the villa had an appearance of architectural unity which belies its composite history.

At its peak the villa incorporated four bath suites, 16 mosaic floors and 11 rooms with under-floor heating. It was abandoned in the fifth century AD.

\section{THE SURVEY OBJECTIVES AND METHODOLOGY}

While the courtyard villa buildings are impressive enough, it was always supposed there was more surrounding them. John Ward in 1911 had conjectured there might be a lower courtyard on the south-east side of the villa, similar to those found at Bignor and Woodchester. ${ }^{18}$ The drought of 1943 revealed an extension to the south-west of the villa in parchmarks in the field, captured by Riley. ${ }^{19}$ These findings were complemented by other aerial photographs taken by Keith St Joseph in 1957, who conjectured that the potential structure could be an aisled barn or hall. The structure measured $c .32 \times 12 \mathrm{~m}$, and had a verandah added along the south-east side which appeared to be fronted by a metalled track way.

Wilson drew together the evidence for his new plan (FIG. 1). The chief additions were two ranges of farm buildings flanking a metalled track on much the same alignment as the south-east range of the main courtyard. Also important was the discovery of what appeared to be the south-west extremity of the north-west range of the courtyard, which seemingly projected some way beyond the great dining-room (Room 1) and the already known portions of the south-west range. A southwestern enclosure-wall ran outside these new discoveries and up the hill, where it turned to enclose a paddock or walled garden; other markings revealed the presence of drains and foundations of several periods. ${ }^{20}$ One of the conclusions of Wilson's reassessment was that geophysical survey might bring greater precision and detail to the aerial images.

The villa is situated on the edge of the alluvium flood plain of the River Evenlode, sitting on a bed of Northmoor sand and gravels at the base of the limestone slopes. The gradiometry survey was performed using a Bartington 601-2 dual gradiometer system (resolution of $0.25 \mathrm{~m} \mathrm{x} 0.5 \mathrm{~m}$ ), 
conducted in the late spring of 2013 on two sets of dates. Our interpretation has not tried to reinvent the plan of the villa. Significant work has taken place by Wilson based upon extant evidence (and the now lost notebooks of O'Neil) to create a revised plan of the site. This has been digitised and superimposed upon the geophysical results.

\section{RESULTS AND INTERPRETATION (FIGS 2-3)}

\section{THE EARLIEST FIELDBOUNDARIES}

Ellis et al. reported that under Rooms 26A and 26B in the northern corner of the villa, there was a deep feature (F1) running east-west. ${ }^{21}$ This predated the villa though was poorly defined and did not appear on any plans. Given its orientation and early date, it could relate to two other major east-west features seen in the geophysical data: two parallel linears about $25 \mathrm{~m}$ apart, which do not appear otherwise to relate to the layout of the developed villa complex.

\section{THE QUARRIES AND THE CONSTRUCTION OF THE VILLA}

During the excavations, a number of large gravel pits were identified from early in the sequence. These were eventually built over by the north-east and south-west ranges. The builders were still clearly aware of them as they took remedial action by initially avoiding these areas and then strengthening the walls.

The south-west range was initially extended as far as rooms 54-55, fronted by Corridor 60b. The initial extension may have ended there because of the existence of a filled-in gravel pit, which lay just beyond; the end-wall was provided with extra-deep foundations to ensure stability. ${ }^{22}$ The pit was around $3.7 \mathrm{~m}$ wide, $15 \mathrm{~m}$ long and $2.8 \mathrm{~m}$ deep. ${ }^{23}$ When the south-west range was extended further east, 'special measures were taken to carry one of the principal walls across the old gravel pit: the north-east wall of Rooms 56 and 59 was reinforced by the provision of substructures to carry its weight over made ground.' ${ }^{24}$ The Aerial photography suggested a square room or building south-west of Room 53, but this was not clear in the geophysics, though there was interference from a metal fence at this point so it may have been obscured.

Another gravel pit lay at the eastern end of the north-east range; rooms 41 and 43 contained subsiding floors, and the north wall was supported by three large rectangular projections. ${ }^{25}$

In addition to these, the geophysics suggested a series of large extraction pits higher up the slope as well, though here they would have been quarrying into the limestone, rather than gravel. Most are $10-15 \mathrm{~m}$ in diameter and semi-circular as they cut into the side of the hill. It is likely that these quarries are associated with the construction of the villa.

\section{REALIGNMENT OF THE LANDSCAPE}

A reorganisation of the landscape seems to have taken place as the villa developed into its full courtyard form. A new road was constructed from the axially-centred entrance into the complex, leading south-south-west between the two buildings identified in the aerial photographs. The one to the west of the road showed more clearly on the aerial photographic plots than the gradiometery, while the hall to the east was much more ephemeral. This was also demonstrated by some experimental GPR results (not reproduced here).

Including these southerly 'halls', there appears to have been a ditch and a wall bounding the south-western side of the complex. There is a standard positive linear feature (ditch) with a fainter parallel negative feature, which together look like the walls of the buildings. It is quite possible that this wall/bank and ditch run $150 \mathrm{~m}$ west-north-west up the hill from the road, where it turns ninety-degrees to form what may be a square enclosure surrounding the entire complex. 
The floodplain to the east of the villa is relatively clear. There are signs of an older palaeochannel, suggesting the river has shifted its course over the years, though there is no evidence for dating this occurrence. The palaeo-channel does, however, have a fairly straight edge to it, in comparison to its current winding path, as if this might represent canalisation at this point in front of the formal villa structure.

There are slight hints of a building at the southern end of this field, with one of its walls running parallel to the 'new halls' to the north-west, but it is decidedly ambiguous. It is possible that this feature relates to the walls identified by David Miles in 1979, but this would mean that the drainage channel cut by the farmer stretched the entire length of the field. Without further details regarding the watching brief, this will remain uncertain. Otherwise, no other features showed up in the gradiometry results in the floodplain field which might relate to Miles' observations.

There is, however, a large geomagnetic anomaly axially aligned with the entrance way, which looks like a large pit, $c .7 \times 12 \mathrm{~m}$. Interpretation of this feature is difficult as any excavation here is likely to hit the water-table relatively rapidly. A central shrine or pool associated with the villa is a remote possibility, but the feature could also be entirely unrelated.

The road running to the south takes a sharp staggered turn towards the edge of the survey area. This relates to the topography. The roadway heading south is leading directly towards s steep rise in the land formed by a spur of the valley side. Whether the road continued on the southern side of the bank or forded the fairly shallow stream is not clear; though this is clearly the main access road into the villa.

\section{MODERN METALLIC DISTURBANCE}

A great density of metallic noise lay in the long grass within the public-access area, to the west and north of the villa. This correlates with where picnicking takes place and modern debris is likely to be found. The significant noise to the north had no obvious surface explanation, but provides a response similar to spoil heaps on some other surveys. Along the edges of some of the fields the barbed wire fences showed themselves, as did a major utility pipe along the western edge of the survey area parallel to the road.

\section{DISCUSSION}

In terms of parallels, North Leigh has been discussed extensively in the standard Roman villa literature amongst other 'courtyard villas' which were formed from the 'tidying up' and agglomeration of pre-existing buildings, such as at Bignor, ${ }^{26}$ Fishbourne ${ }^{27}$ and Darenth. ${ }^{28}$

In terms of the new features, the large rectangular enclosure surrounding the entire complex has a potential parallel at Brading (IoW) where similar linear features have been revealed by geophysics. ${ }^{29}$ At Bignor (W Sussex), which is also of a similar date, size and type to North Leigh, its fourth-century AD courtyard villa form became enclosed by a large wall which incorporated the extra buildings. Similarly at Bancroft (Bucks), the mid-fourth-century to early fifth-century phase received a large ditched enclosure running externally to what was potentially a courtyard-type complex, and which overlay (reorganised?) a pre-existing villa settlement and field-system. ${ }^{30}$

In terms of the evidence for the surrounding field system, the area surveyed at North Leigh is still relatively small compared to that at, say, Brading. It is not possible to make sense of all of it, but a reorganisation and re-orientation is clearly apparent. This is unlike some other sites where large scale surveys have taken place, such as at Dunkirt Barn (Hants). Here the site developed from a late banjo enclosure into a large winged-corridor villa and garden enclosure, but the fence lines always respected the larger, earlier settlement enclosure. ${ }^{31}$ 
In terms of the floodplain location of North Leigh villa, there are numerous courtyard villas lying alongside rivers which are easy to pick out (Kent has a few of the higher status examples). In particular, at Darenth villa, located alongside the River Darent, a large aisled hall structure lay to the south-east of, and external to, the main courtyard enclosure, as did one of its bathhouses (Philp 1984). Fishbourne Palace included Building 3, which was constructed before the palace, but continued in use lying right in front of the main structure, apparently obstructing its view to approaching people, who would have used the metalled trackways running past it into the main Palace $^{32}$. Fishbourne is clearly not contemporary with the final phase at North Leigh but it, along with other examples, shows that courtyard villas were not always isolated buildings lying within 'open' landscapes.

The possible canalisation of the adjacent river at North Leigh also has parallels, including Darenth and Fishbourne already mentioned, as well as the villa at Fullerton (Hants). All three of these villas have produced remains of large millstones, with Darenth and Fullerton also including structural evidence which would support the undertaking of milling at the sites, providing a context for the canalising of their respective rivers ${ }^{33}$. Only with further excavation at North Leigh would this possibility be proven.

The University of Reading (J.C. and M.A)

j.d.creighton@reading.ac.uk

m.g.allen@reading.ac.uk

\section{Bibliography}

Anon. 1944: 'Roman Britain in 1943: sites explored', Journal of Roman Studies 34, 76-85

Case, H. 1958: ‘Archaeological Notes’, Oxoniensia 23,133-4

Copeland, T. 1988: 'The North Oxfordshire Grim’s Ditch: A fieldwork survey', Oxoniensia 53, 277-92

Cunliffe B. 1971: Excavations at Fishbourne 1961-1969. Society of Antiquaries of London Research Report 26, London

Cunliffe B. 2013: The Roman Villa at Brading, Isle of Wight: The Excavations of 2008-10. Oxford University School of Archaeology Monograph No. 77

Cunliffe B. and Poole C. 2008a: The Danebury Environs Roman Programme: a Wessex Landscape during the Roman Era. Vol. 2 the sites, part 7: Dunkirt Barn, Abbotts Ann, Hants, 2005 and 2006. Oxford University School of Archaeology Monograph No. 71

Cunliffe B. and Poole C. 2008b: The Danebury Environs Roman Programme: a Wessex Landscape during the Roman Era. Vol. 2 the sites, part 3: Fullerton, Hants, 2000 and 2001. Oxford University School of Archaeology Monograph No. 71

Ellis, P., Bevan, L., Blagg, T., Esmonde Cleary, S., Henig, M., Pinter-Bellows, S. and Timby, J. 1999: 'North Leigh Roman Villa, Oxfordshire: A Report on Excavation and Recording in the 1970s', Britannia 30, 199-246

Fine, D. 1976: 'An Excavation of the North Oxfordshire Grim's Ditch at North Leigh', Oxoniensia 41, $12-13$ 
Frere, S.S. 1982: ‘The Bignor villa’, Britannia 13, 135-195

Frere, S.S., Hassall, M.W.C. \& Tomlin, R.S.O. 1977: 'Roman Britain in 1976', Britannia 8, 356-449

Goodburn, R., Wright, R.P., Hassall, M.W.C. \& Tomlin, R.S.O. 1976: 'Roman Britain in 1975', Britannia 7, 291-392

Goodburn, R., Hassall, M.W.C. \& Tomlin, R.S.O. 1978: 'Roman Britain in 1977', Britannia 9, 404-85

Hakewll, H. 1823: 'Wooton Hundred', in J. Skelton, Antiquities of Oxfordshire: Skelton's engraved illustrations of the principal antiquities of Oxfordshire from original drawings by F Mackenzie. Accompanied with descriptive and historical notices, Oxford

Hakewill, H. 1826a: An Account of Roman Villa Discovered at Northleigh and Stonesfield, Oxford

Hakewill, H. 1826b: An Account of Roman Villa Discovered at Northleigh, Oxfordshire, in the years 1813, 1814, 1815, 1816, London

Henig, M. and Booth, P. 2000: Roman Oxfordshire, Sutton, Stroud

Leeds, E.T. and Atkinson, R.J.C. 1943: ‘Archaeological Notes’, Oxoniensia 8, 193-201

Manley, J. and Rudkin D. 2003: Facing the Palace: excavations in front of Fishbourne Roman Palace (Sussex, UK) 1995-99, Sussex Archaeological Collections 141, Lewes

Morrison, M.E.S. 1959: 'Carbonized cereals from the Roman villa of North Leigh, Oxon.', Oxoniensia $24,13-21$

Philp B. 1984: Excavations in the Darent Valley, Kent. Fourth Research Report in the Kent Monograph series, Kent Archaeological Rescue Unit, Dover Castle, Kent

Taylor M.V. 1923: The Roman Villa at North Leigh, Clarendon Press, Oxford

Taylor M.V., 1939: 'Romano-British Remains: Country Houses', in W. Page (ed.) The Victoria History of the Counties of England. A History of Oxfordshire I, 306-23.

Ward, J. 1911: Romano-British Buildings and Earthworks, Methuen, London

Williams R.J. and Zeepvat R.J. 1994: Bancroft: a Late Bronze Age/Iron Age Settlement, Roman Villa and Temple Mausoleum. Buckinghamshire Archaeological Society Monograph 7, Aylesbury

Wilson, D.R. and Sherlock, D., 1980: North Leigh Roman Villa: DoE Official Handbook, HMSO, London Wilson, D.R. 2004: 'The North Leigh Roman Villa: its Plan Reviewed', Britannia 35, 77-113

\section{ILLUSTRATIONS}




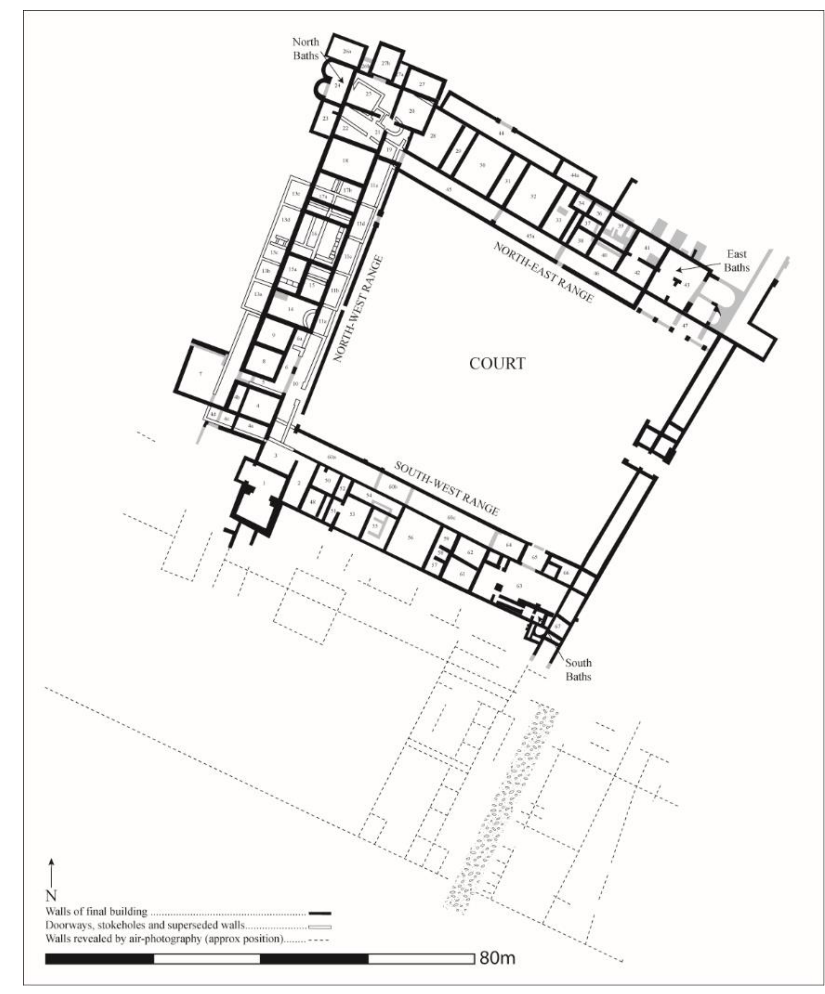

FIG 1: D.R. Wilson's plan of 1977 (redrawn from Wilson 2004, 79) 


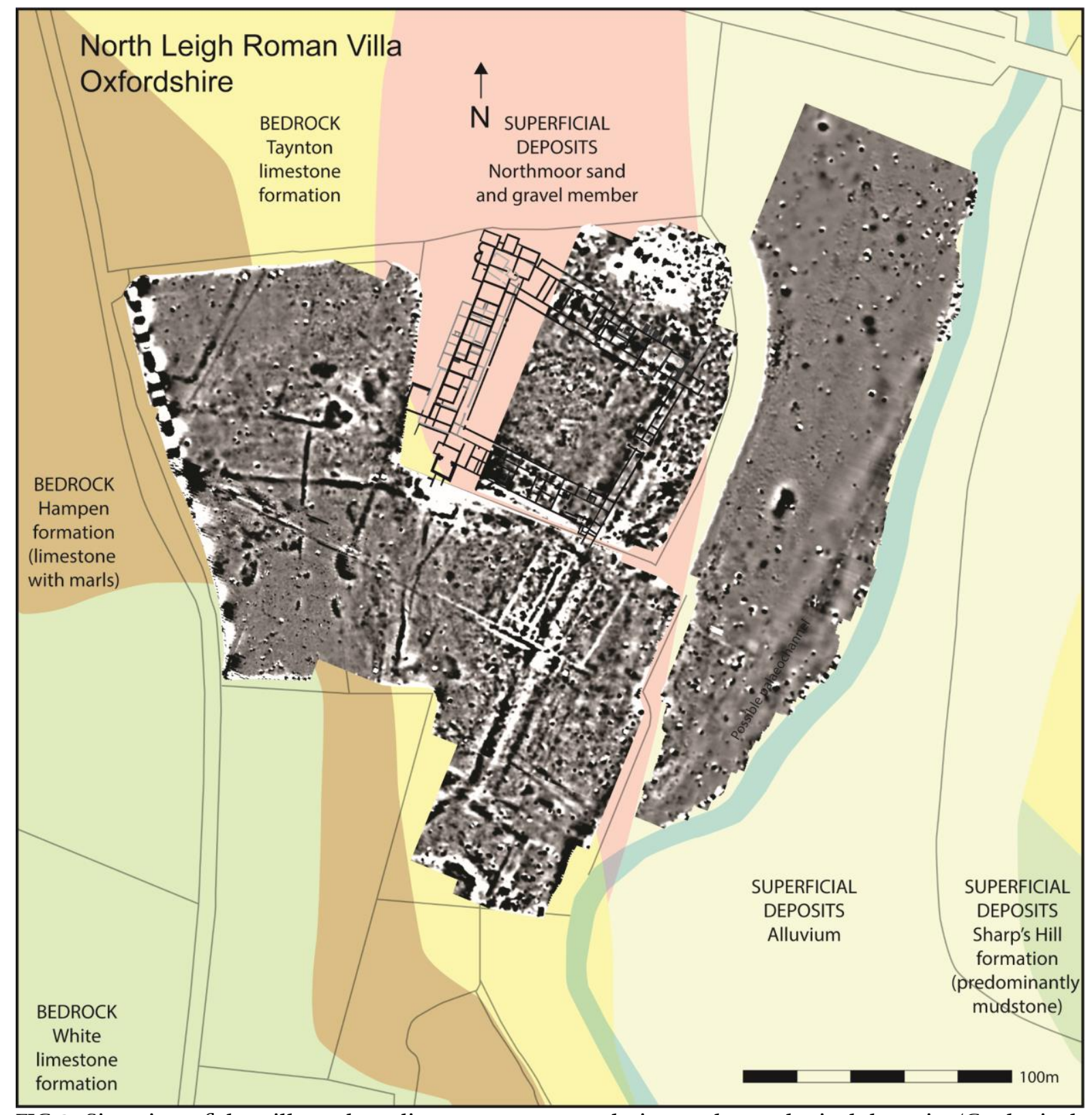

FIG 2: Situation of the villa and gradiometery survey relative to the geological deposits (Geological map data (C) NERC 2012, crown copyright, supplied through EDINA). Gradiometery survey, shown at $\pm 3 \mathrm{nT}$ (black is $+3 \mathrm{nT}$, white is $-3 \mathrm{nT}$ ). 


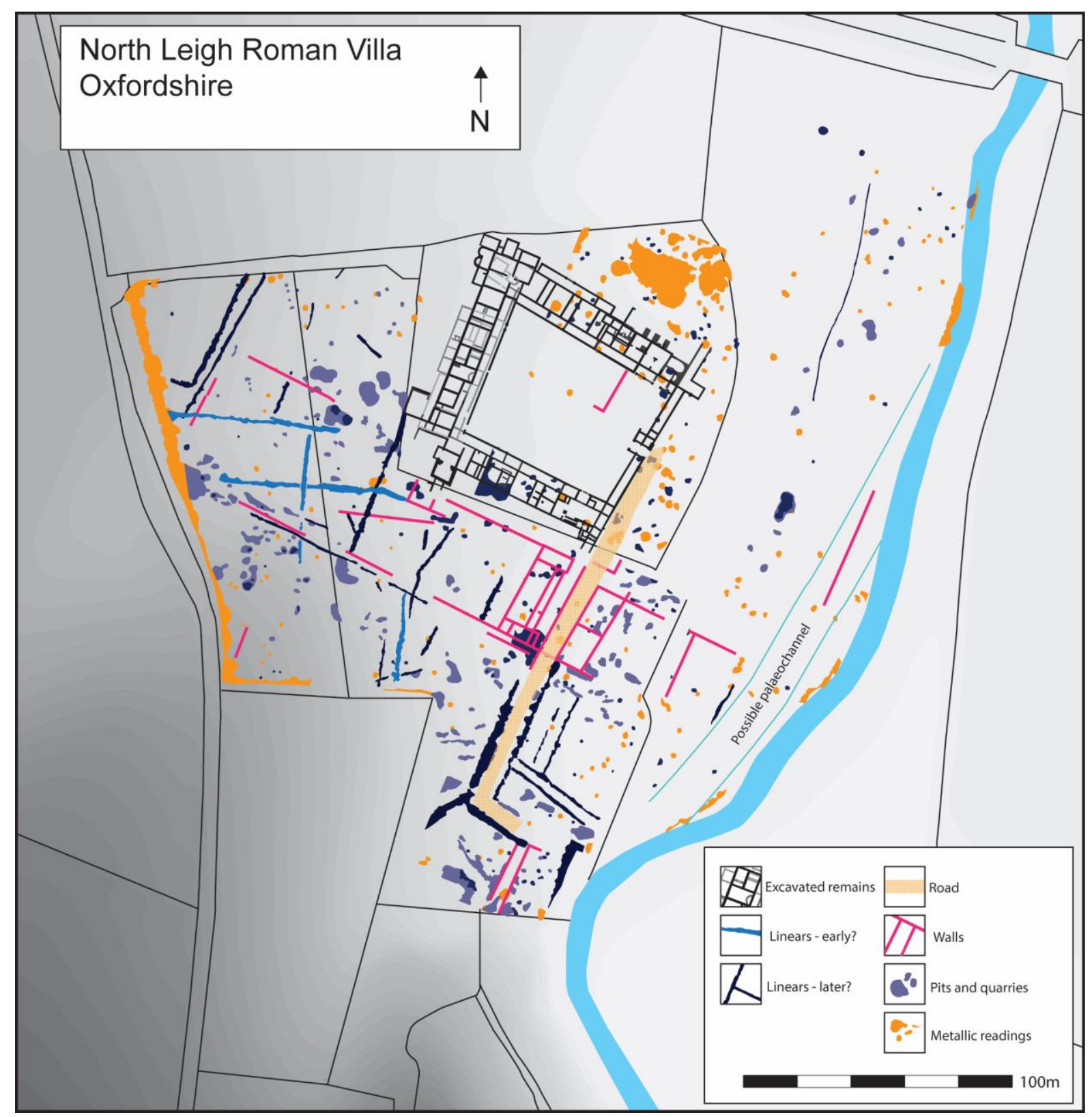

FIG 3: Gradiometery interpretation

\section{ENDNOTES}

Henig and Booth 2000

Fine 1976, Copeland 1988

The project team from University of Reading included: Martyn Allen, Tom Brindle, John Creighton, Anne Sassin, Alexander Smith and Dave Thornley. We would like to thank the custodian, English Heritage, and the landowner, Blenheim Palace, of the site for their assistance in facilitating the fieldwork. In particular, we are grateful to Pam Braddock (EH), Roy Porter (EH), Richard Massey (EH), Chris Welch (EH), Matthew Neilson (BP) and Paul Orsi (BP) for their support.

Morrison 1959, 13

Wilson 2004, 77-80

Hakewill 1823, 9-16; 1826a; 1826b

First recorded in 1921 in EH records 


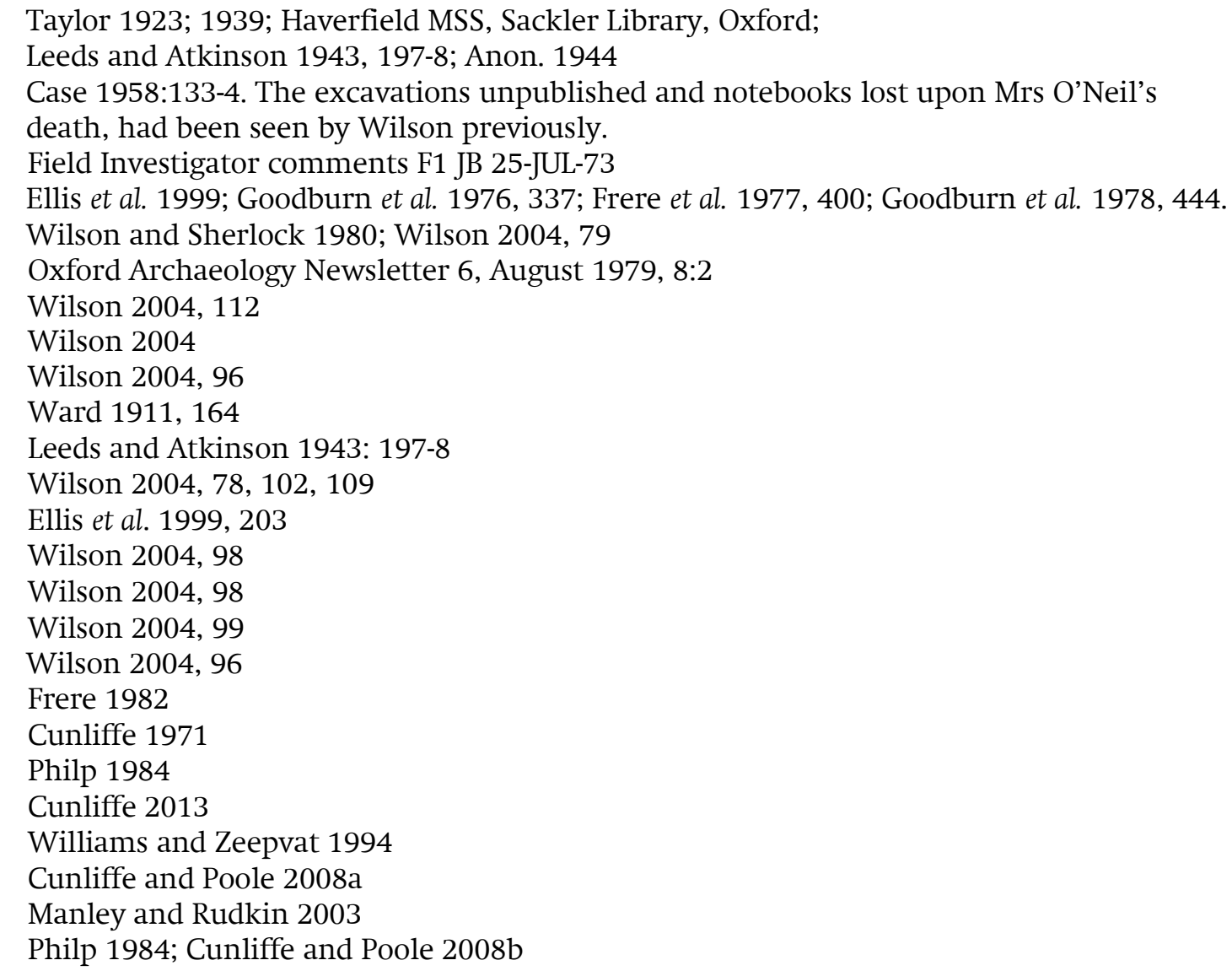

